\title{
Peptide YY Measurement
}

National Cancer Institute

\section{Source}

National Cancer Institute. Peptide YY Measurement. NCI Thesaurus. Code C80202.

The determination of the amount of peptide YY present in a sample. 